\title{
Bilingualism as a strategy to delay the onset of Alzheimer's disease
}

This article was published in the following Dove Press journal:

Clinical Interventions in Aging

19 October 2017

Number of times this article has been viewed

\author{
Blanka Klimova ${ }^{1,2}$ \\ Martin Valis ${ }^{2}$ \\ Kamil Kuca ${ }^{3,4}$ \\ 'Department of Applied Linguistics, \\ Faculty of Informatics and \\ Management, University of Hradec \\ Kralove, ${ }^{2}$ Department of Neurology, \\ ${ }^{3}$ Biomedical Research Centre, \\ University Hospital Hradec Kralove, \\ ${ }^{4}$ Department of Chemistry, Faculty of \\ Science, University of Hradec Kralove, \\ Hradec Kralove, Czech Republic
}

Correspondence: Kamil Kuca Biomedical Research Centre, University Hospital Hradec Kralove, Sokolska 58I, 50005 Hradec Kralove, Czech Republic Tel +420603289166

$\mathrm{Fax}+420495835200$

Email kamil.kuca@fnhk.cz

\begin{abstract}
The purpose of this study is to explore original studies which provide evidence about the effects of bilingualism on the delay of the onset of dementia, specifically Alzheimer's disease (AD). A literature review was conducted in the world's acknowledged databases: Web of Science, Scopus, and MEDLINE. Altogether, 14 original studies focusing on the research topic were detected. These included six prospective cohort studies and eight retrospective studies. Both types of studies suggest different conclusions. The findings from the prospective cohort studies state that there is no association between bilingualism and the delay of the onset of $\mathrm{AD}$, while the retrospective studies claim the opposite. Despite the negative results of the prospective cohort studies, more research should be conducted on bilingualism and its impact on the delay of the onset of $\mathrm{AD}$, since the brain studies have brought positive findings as far as the enhancement of cognitive reserve is concerned.
\end{abstract}

Keywords: older people, evidence, effectiveness, review, cognition

\section{Introduction}

\section{Aging and dementia}

According to the recent report of the United Nations ${ }^{1}$ on the aging process of the world's population, the number of older people aged $60+$ years has risen considerably. Globally, the number of these elderly people is growing faster than the number of people in any other age group. This accelerating trend in the rise of older population groups inevitably results in serious economic and social changes accompanied with a number of aging diseases such as dementia.

Dementia, specifically Alzheimer's disease (AD), together with heart diseases, cancer, and respiratory diseases, is one of the most common causes of death among older people. ${ }^{2}$ Globally, dementia affects around 58 million people, and it is estimated that the number of older people with dementia would triple by 2050 , since each year about 9.9 million new dementia cases are diagnosed worldwide. ${ }^{3,4}$

Dementia is a syndrome of deterioration of cognitive functions that interferes with a patient's everyday life. This cognitive impairment has an enormous impact not only on the patient's health and his/her self-care but also on the costs of care, either at home or in a residential establishment. ${ }^{5-7}$ Therefore, there is sustainable effort to prevent cognitive decline which is the foremost sign of this neurological disorder. However, currently, there is no effective pharmacological treatment for the cognitive decline. ${ }^{8}$ Thus, there is an increasing interest in non-pharmacological alternative approaches which may maintain or even increase the so-called cognitive reserve and enable healthy older people to delay the deterioration of cognitive functions. 


\section{Cognitive reserve, its enhancement, and bilingualism}

Cognitive reserve can be defined as the resilience to neuropathological damage of the brain. ${ }^{9}$ It is assumed that this is the result of experience-based neural changes which are caused by a physically and mentally stimulating lifestyle. ${ }^{10}$ Research ${ }^{11}$ indicates that especially the differences in cognitive reserve are affected by environmental enrichment. This means that although some people have signs of brain atrophy and neuronal loss, thanks to their cognitive reserve, they do not have visible difficulties in cognitive functioning.

A research study ${ }^{12}$ revealed that $60 \%$ of general cognitive ability is of genetic origin, but there are some nonpharmacological activities such as performing physical and mental activities, which play an important role in its enhancement as well. ${ }^{13}$ Antoniou et $\mathrm{al}^{10}$ claim that some of these non-pharmacological activities which are aimed at the stimulation of the cognitive functions might delay the cognitive decline.

One of these mental activities, which may also contribute to the enhancement of cognitive reserve, is bilingualism, that is, the ability to speak more than one language. In fact, bilingualism enables constant shifting between languages, with their distinct sounds, words, concepts, and grammatical rules, and offers effective training of executive functions such as attention, switching, inhibition, and monitoring. All these contribute to a higher cognitive reserve. ${ }^{14}$ Thus, bilingualism is considered to be connected with cognitive advantage, ${ }^{15}$ since research ${ }^{16}$ has shown that language does not only reflect the mind but also modify the brain to certain degree even in older age. Bak et al, ${ }^{17}$ Goral et al, ${ }^{18}$ and Luk et $\mathrm{al}^{19}$ report that bilingual people may enhance their cognitive reserve at later age, thanks to the use of two languages, and the so-called mental flexibility. Schweitzer et $\mathrm{al}^{20}$ argue that bilingualism is a clear case of an environmental factor that helps produce cognitive reserve, although it might also affect the brain and its development and organization, and contribute to brain reserve. There are several brain studies which confirm that bilingual people usually have greater gray matter volume than monolingual individuals, which has a positive impact on the functional connectivity between gray matter regions. ${ }^{21-24}$ Therefore, bilingualism seems to protect against the cognitive decline that occurs during aging. This has also been confirmed by the most recent study by Estanga et al, ${ }^{25}$ who conclude that bilingualism influences cognitive reserve, especially improving executive and visualspatial functions.
Bialystok et $\mathrm{al}^{26}$ claim that thanks to better mental flexibility, bilingual people have the ability to adapt to constant changes and process information effectively and adaptively. Furthermore, Lee and Tzeng ${ }^{27}$ indicate that effective connectivity, thanks to second language learning, improves the capacity for language processing and general executive control by reorganizing neural circuitries. This even concerns older learners whose age is considered to be far from the so-called critical period of language acquisition. These findings have also been confirmed by Schlegel et al ${ }^{28}$ who have revealed that the brain maintains its plasticity in adult age. In their study on language learning with 11 English speakers studying Chinese for nine months, they have brought evidence that white matter in older individuals might still experience considerable changes which have a positive impact on foreign language learning in aging. Bialystok ${ }^{29}$ points out that the age in second language acquisition is not such a significant factor, but the length of exposure to the target language is important.

The purpose of this study is to explore original studies which provide evidence about the effects of bilingualism on the delay of the onset of $\mathrm{AD}$.

\section{Methods}

The methodology of this study was based on Moher et al. ${ }^{30}$ A literature review was conducted in Web of Science, Scopus, and MEDLINE databases with the goal of identifying research studies on the basis of the following key words: bilingualism AND cognitive decline, bilingualism AND dementia, and bilingualism AND AD. This review identified articles published during 2007 to May 2017.

Most of the studies on the research topic were identified in the Web of Science (146), followed by MEDLINE (129) and Scopus (104). Altogether, 379 publications were detected in the databases. The titles of all studies were checked in order to confirm whether they focused on the research topic and to eliminate duplicates. Ninety-eight studies were used for further analysis, in which the authors checked the content of the abstracts. Sixty studies were selected for the full-text analysis, out of which the findings of 14 studies were then used for the detailed analysis of the research topic (Figure 1).

A study was included if it matched the corresponding period, that is, from 2007 up to May 2017. The selection period started with the year of 2007 , since this is the year when the first findings on the efficacy of bilingualism on the delay of the onset of dementia appeared. ${ }^{26}$ Furthermore, 


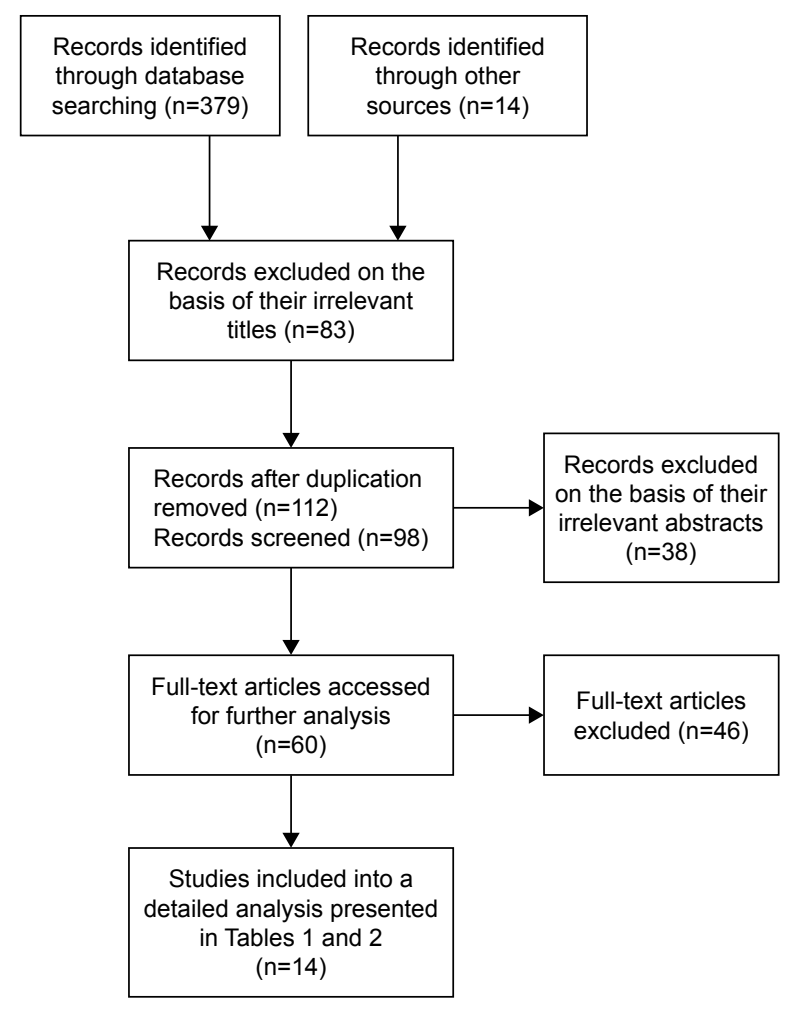

Figure I Results of the selection procedure.

a study was included if it involved older people and focused on the topic of bilingualism, that is, the ability to speak and write more than one language, and its effect on the onset of AD. The studies which focused only on AD were included, while the studies concentrating on other, less frequent dementias, such as frontotemporal dementia ${ }^{31}$ or Parkinson's diseases, were excluded. ${ }^{32}$ The studies ${ }^{18,33}$ that compared the performance of bilinguals to that of monolinguals on tasks such as nonverbal tasks, assumed to measure executive functioning, were excluded, as well as multilingual studies. ${ }^{34,35}$ The brain studies ${ }^{21-25}$ were also excluded. Only studies written in English were included.

\section{Findings}

Altogether, 14 original studies focusing on the research topic were detected. These included six prospective cohort studies (Table 1) and eight retrospective studies (Table 2). All studies except two ${ }^{38,45}$ compared both monolingual and bilingual language groups. Tables 1 and 2 provide an overview of the main findings on bilingualism and its effect on the delay of the onset of AD. The studies are presented in the alphabetical order of their first author.

The research period of the prospective studies ranges between 5 and 50 years. Overall, the number of participants in these six studies was 8,233. All six studies in fact met the criteria for the evaluation of the quality of cohort studies set by the Newcastle-Ottawa Scale, ${ }^{48}$ since they applied evidence-based measurement of their outcomes, such as a battery of cognitive performance tests, clinical examinations, or Cox regression. Furthermore, the followed-up period lasted 5 years at minimum, the clinical samples were derived from community samples and not referrals to specialist memory clinics, and most importantly, the age of the onset of $\mathrm{AD}$ was determined by standardized clinical examinations and not by subjective retrospective self-reports. In some studies, however, the self-reports were used for the assessment of language proficiency. ${ }^{36,39,40}$ As Zahodne et $\mathrm{al}^{40}$ indicate, this should not have any effect on the overall results. Apart from two studies, ${ }^{17,38}$ the findings suggest that there is no association between bilingualism and the delay of the onset of dementia, specifically AD.

On the contrary, the results of all retrospective studies with one exception ${ }^{43}$ indicate that bilingualism might delay the onset of cognitive decline, specifically AD, by approximately 4.5 years. However, the number of subjects in these studies is lower than in the prospective studies. Altogether, 1,502 patients participated in the research, ranging from 44 to 648 patients. Bakker ${ }^{49}$ points out that in order to attain desirable levels of power, at least 139 subjects should be involved in each language group. Criterion for bilingualism in these studies is that individuals should speak two or more languages fluently, approximately $50 \%$ of the time, ideally daily, at least since their early adulthood. In addition, the findings on the age of the onset of $\mathrm{AD}$ are based on questionnaires and interviews with these patients, their family members, or caregivers, which might also contribute to the misinterpretation of these results. Generally, retrospective studies usually have more potential sources of bias and confounding than prospective studies..$^{50}$

\section{Discussion}

As research on bilingualism reveals, there has been an increased interest in how and whether lifelong bilingualism protects the brain from cognitive decline, specifically from the symptoms of AD. ${ }^{51}$ However, the results in favor of bilingual advantage differ as the findings from the selected research studies shown in Tables 1 and 2. Almost all retrospective studies in Table 2 demonstrate the delay of the onset of dementia by 4.5 years and manifest that bilingualism contributes to the enhancement of cognitive reserve. This has also been confirmed by recent review studies. ${ }^{51,52}$ Bialystok et al, ${ }^{52}$ 
Table I An overview of the prospective cohort studies on bilingualism and its effect on the delay of the onset of AD

\begin{tabular}{llll}
\hline Study & Objective & $\begin{array}{l}\text { Number of } \\
\text { subjects }\end{array}$ & Main outcome measures \\
\hline $\begin{array}{l}\text { Bak et al }{ }^{17} \\
\text { Prospective study } \\
(50 \text { years })\end{array}$ & $\begin{array}{l}\text { To explore the effect of } \\
\text { bilingualism on later-life } \\
\text { cognition controlling for } \\
\text { childhood intelligence }\end{array}$ & 853 participants & $\begin{array}{l}\text { First tested at age II and then } \\
\text { at the age of } 70 ; \text { a series of }\end{array}$ \\
& & cognitive tests for participants \\
& & including intelligence test, and \\
& & $\begin{array}{l}\text { comparing the results with } \\
\text { their own test scores at the } \\
\text { age of II }\end{array}$
\end{tabular}

Lawton et $\mathrm{al}^{36}$
Prospective cohort
study (10 years)

Sanders et $\mathrm{al}^{37}$ Prospective cohort study (I7 years)

Wilson et $\mathrm{al}^{38}$ Prospective cohort study (5.8 years)

Yeung et $\mathrm{al}^{39}$ Prospective cohort study (5 years)

Zahodne et $\mathrm{al}^{40}$ Prospective cohort study (23 years)
To explore if clinically diagnosed $A D$ and vascular dementia occurred later for bilingual than monolingual, immigrant, and US-born, Hispanic Americans To verify whether $n-N E S s$ have lower risk of incident dementia/AD and that educational level might modify this relationship

\section{To test the hypothesis} that foreign language and music instruction in early life are associated with lower incidence of $\mathrm{MCl}$ and slower rate of cognitive decline in old age To determine whether bilingualism is associated with dementia in crosssectional or prospective analyses of older adults To test the hypothesis that dementia is diagnosed at older ages in bilinguals compared to monolinguals

\section{I,789 community- dwelling Hispanic Americans, aged $\geq 60$ years}

I,944 healthy older individuals $\geq 70$ years

964 healthy older individuals
Cognitive testing, clinical examination, and self-report using a three-point Likert-type scale for the evaluation of language proficiency

\section{Battery of cognitive} performance tests at baseline and each successive annual evaluation, and nested Cox proportional hazards models were used

Cognitive testing and clinical classification of $\mathrm{MCl}$

Self-reports, cognitive testing, and clinical examination adults

I,067 healthy older Hispanic immigrants in New York

\author{
Self-report using a four- \\ point Likert-type scale for \\ the evaluation of language \\ proficiency, Selective \\ Reminding Test, Boston \\ Naming Test, tests of verbal \\ and nonverbal abstraction and \\ letter fluency, Color Trails \\ Test, and Cox regression
}

Results

The results show that bilinguals, as well as those who acquired a second language at the later age, performed significantly better than predicted from their baseline cognitive abilities, with strongest effects on general intelligence and reading; the findings also suggest a positive effect of bilingualism on later-life cognition, including in those who acquired their second language in adulthood The findings show that mean age of dementia diagnosis was not significantly different for bi/monolingual, US-born or immigrant, Hispanic Americans

n-NES status does not appear to have an independent protective effect against incident dementia/ $A D$, and that n-NES status may contribute to risk of dementia in an education-dependent manner The results indicate that higher levels of foreign language and music instruction during childhood and adolescence are associated in old age with lower risk of developing $\mathrm{MCl}$ but not with the rate of cognitive decline The results reveal that there is no association between speaking more than one language and dementia

The findings do not support a protective effect of bilingualism on age-related cognitive decline or the development of dementia

Abbreviations: AD, Alzheimer's disease; $n-N E S s$, non-native English speakers; $\mathrm{MCl}$, mild cognitive impairment.

by comparing monolingual and bilingual older individuals on measures of cognitive function and brain structure, emphasize that bilingualism is a protective factor against the symptoms of dementia. Nevertheless, their review leaves out some of the important prospective studies on this topic. ${ }^{36,37,39}$ The same is true for the study by Alvarez and Rodriguez. ${ }^{53}$

On the contrary, the findings from the prospective studies exert nonsignificant results as far as the bilingual advantage is concerned. The latest meta-analytic review study provides conclusive results about this. ${ }^{54}$ Mukadam et $\mathrm{al}^{54}$ on the basis of effect sizes (odds ratio of dementia of 0.96 [95\% CI $0.74-1.23]$ in bilingual participants $[n=5,527]$ compared to monolinguals) from the analyzed studies have concluded that there is no evidence that bilingualism protects from cognitive decline or dementia. The retrospective studies they detected could not be analyzed for effect sizes, since 
Table 2 An overview of the retrospective and cross-sectional studies on bilingualism and its effect on the delay of the onset of AD

\begin{tabular}{|c|c|c|c|c|}
\hline Study & Objective & Number of subjects & Main outcome measures & Results \\
\hline $\begin{array}{l}\text { Alladi } \\
\text { et } \mathrm{al}^{41}\end{array}$ & $\begin{array}{l}\text { To determine the association } \\
\text { between bilingualism and age } \\
\text { at onset of dementia and its } \\
\text { subtypes, taking into account } \\
\text { potential confounding factors }\end{array}$ & $\begin{array}{l}648 \text { patients } \\
\text { with dementia } \\
\text { ( } 391 \text { bilinguals, } \\
257 \text { monolinguals) }\end{array}$ & $\begin{array}{l}\text { The Mini-Mental State } \\
\text { Examination, Addenbrooke's } \\
\text { Cognitive Examination - revised, } \\
\text { the Clinical Dementia Rating } \\
\text { scale, and clinical examination }\end{array}$ & $\begin{array}{l}\text { The findings indicate that bilingual } \\
\text { patients developed dementia } \\
4.5 \text { years later than the monolingual } \\
\text { ones; there is a bilingual advantage in } \\
\text { those who are illiterate }\end{array}$ \\
\hline $\begin{array}{l}\text { Bialystok } \\
\text { et } \mathrm{al}^{26}\end{array}$ & $\begin{array}{l}\text { To examine the effect of lifelong } \\
\text { bilingualism on maintaining } \\
\text { cognitive functioning and } \\
\text { delaying the onset of symptoms } \\
\text { of dementia in old age }\end{array}$ & $\begin{array}{l}\text { I84 patients with } \\
\text { cognitive impairments, } \\
\text { out of whom } 132 \text { had } \\
\text { probable AD; } 51 \% \\
\text { were bilinguals }\end{array}$ & $\begin{array}{l}\text { Clinical examination, } \\
\text { Mini-Mental State Examination, } \\
\text { and interviews }\end{array}$ & $\begin{array}{l}\text { The findings suggest that the } \\
\text { bilinguals may develop symptoms } \\
\text { of dementia } 4 \text { years later than } \\
\text { monolinguals with no effect on its } \\
\text { progression }\end{array}$ \\
\hline $\begin{array}{l}\text { Bialystok } \\
\text { et al }{ }^{42}\end{array}$ & $\begin{array}{l}\text { To explore the effects of } \\
\text { bilingualism on the age of onset } \\
\text { and progression of } \mathrm{MCl} \text { and } \mathrm{AD}\end{array}$ & $\begin{array}{l}\text { I } 49 \text { patients }(74 \mathrm{MCl} \\
\text { patients and } 75 \mathrm{AD} \\
\text { patients) }\end{array}$ & $\begin{array}{l}\text { Three executive function tests } \\
\text { from the D-KEFS battery, } \\
\text { questionnaires, and interviews }\end{array}$ & $\begin{array}{l}\text { The results confirm that bilingual } \\
\text { patients are several years older than } \\
\text { comparable monolinguals at both age } \\
\text { of symptom onset and date of first } \\
\text { clinic visit }\end{array}$ \\
\hline $\begin{array}{l}\text { Clare } \\
\text { et } \mathrm{al}^{43}\end{array}$ & $\begin{array}{l}\text { To investigate whether } \\
\text { bilingualism contributes to the } \\
\text { increased cognitive reserve } \\
\text { or not }\end{array}$ & $\begin{array}{l}86 \text { patients ( } 37 \text { bilingual } \\
\text { and } 49 \text { monolingual } \\
\text { patients) }\end{array}$ & $\begin{array}{l}\text { Standardized neuropsychological } \\
\text { tests and questionnaires }\end{array}$ & $\begin{array}{l}\text { The results show that there was a } \\
\text { nonsignificant difference in age at the } \\
\text { time of diagnosis between bilinguals } \\
\text { and monolinguals; bilingual Welsh/ } \\
\text { English speakers with AD did not } \\
\text { show a clear advantage in executive } \\
\text { function over monolingual English } \\
\text { speakers, but retained some benefits } \\
\text { in inhibition and management of } \\
\text { response conflict }\end{array}$ \\
\hline $\begin{array}{l}\text { Craik } \\
\text { et } \mathrm{al}^{44}\end{array}$ & $\begin{array}{l}\text { To prove that lifelong } \\
\text { bilingualism is a further factor } \\
\text { contributing to cognitive } \\
\text { reserve }\end{array}$ & $\begin{array}{l}211 \text { consecutive } \\
\text { patients diagnosed } \\
\text { with probable AD } \\
\text { (102 bilinguals, } \\
109 \text { monolinguals) }\end{array}$ & $\begin{array}{l}\text { Clinical examination, } \\
\text { Mini-Mental State Examination, } \\
\text { and interviews }\end{array}$ & $\begin{array}{l}\text { The results reveal that the bilingual } \\
\text { patients had been diagnosed } \\
4.3 \text { years later and had reported the } \\
\text { onset of symptoms } 5.1 \text { years later } \\
\text { than the monolingual patients }\end{array}$ \\
\hline $\begin{array}{l}\text { Gollan } \\
\text { et } \mathrm{al}^{45}\end{array}$ & $\begin{array}{l}\text { To explore the relationship } \\
\text { between bilingual language } \\
\text { proficiency and onset of } \\
\text { probable AD }\end{array}$ & $\begin{array}{l}44 \text { Spanish-English } \\
\text { bilinguals with probable } \\
\text { AD }\end{array}$ & Boston Naming Test & $\begin{array}{l}\text { The findings indicate that bilingualism } \\
\text { along a continuum enhances cognitive } \\
\text { reserve; significant effects were only } \\
\text { attained in low-education groups }\end{array}$ \\
\hline $\begin{array}{l}\text { Ossher } \\
\text { et al }{ }^{46}\end{array}$ & $\begin{array}{l}\text { To examine the effect of } \\
\text { bilingualism on } \mathrm{aMCl}\end{array}$ & $\begin{array}{l}\text { I I patients with aMCl } \\
\text { (7I monolinguals, } \\
40 \text { bilinguals) }\end{array}$ & $\begin{array}{l}\text { Battery of neuropsychological } \\
\text { tests, and questionnaires } \\
\text { about their language and social } \\
\text { background }\end{array}$ & $\begin{array}{l}\text { The results show that only individuals } \\
\text { diagnosed with single-domain aMCl } \\
\text { demonstrated a later age of diagnosis } \\
\text { for bilinguals ( } M=79.4 \text { years) than } \\
\text { monolinguals ( } M=74.9 \text { years) }\end{array}$ \\
\hline $\begin{array}{l}\text { Woumans } \\
\text { et al }{ }^{47}\end{array}$ & $\begin{array}{l}\text { To explore the effects of } \\
\text { bilingualism on the clinical } \\
\text { manifestation of } A D\end{array}$ & $\begin{array}{l}69 \text { monolinguals and } \\
65 \text { bilinguals diagnosed } \\
\text { with probable AD }\end{array}$ & $\begin{array}{l}\text { Clinical examination, } \\
\text { Mini-Mental State Examination, } \\
\text { screening blood tests, } \\
\text { neuroimaging, and self-reports }\end{array}$ & $\begin{array}{l}\text { Results indicate a significant delay for } \\
\text { bilinguals of } 4.6 \text { years in manifestation } \\
\text { and } 4.8 \text { years in diagnosis }\end{array}$ \\
\hline
\end{tabular}

Abbreviations: AD, Alzheimer's disease; $\mathrm{MCl}$, mild cognitive impairment; D-KEFS, Delis-Kaplan Executive Function System; aMCl, amnestic mild cognitive impairment.

they incline to confounding by education or cultural differences in presentation to dementia services. This seems to be caused by shortcomings in the conception and assessment of bilinguals and confounding variables. ${ }^{55}$ The most conflicting factors appear to be immigration status, education, group heterogeneity, or social factors. ${ }^{56}$ In prospective studies, bilingualism is usually connected with a higher level of formal education. However, in retrospective studies, there is no consensus on this issue. In some studies, ${ }^{26,44,45}$ monolingual groups have higher mean scores on education than bilingual groups. In addition, Fuller-Thomson and $\mathrm{Kuh}^{57}$ point out that immigrants usually have less morbidity and mortality. Therefore, more research should be performed on bilingualism in a nonimmigrant population and their cognitive decline. In addition, all the demographic data about the participants' background, for example, education, occupation, or immigrant status, should be properly collected.

Thus, the authors of this mini-review agree with Strauss $^{58}$ that although both types of the studies arrive at conflicting conclusions on bilingualism and its impact on the delay of 
the onset of dementia, one thing seems to be sure; speaking or learning another language cannot cause any harm. Furthermore, $\mathrm{Bak}^{14}$ adds that it has no side effects, and Bialystok et $\mathrm{al}^{52}$ emphasize its important role in the reduction of potential costs, both for humans and national economy.

The limitations of this review study involve the use of insufficient and different methodologies, especially in the retrospective studies. This might result in the overestimated effects of the findings, which may have an adverse impact on the validity of these reviewed studies. ${ }^{59,60}$

\section{Conclusion}

Although the findings of this mini-review did not arrive at any revolutionary conclusions, they suggest that more research should be conducted on bilingualism and its impact on the delay of the onset of dementia, since the brain studies have brought positive findings as far as the enhancement of cognitive reserve is concerned.

In addition, Kurdziel et $\mathrm{a}^{61}$ say, learning throughout aging is necessary because older individuals who keep mentally and physically active are less likely to be cognitively impaired and depressed.

\section{Acknowledgments}

This paper is supported by the project Excellence (2017) at the Faculty of Informatics and Management of the University of Hradec Kralove, Czech Republic, and by the research project PROGRES Q40 run at the Medical Faculty of Charles University.

\section{Disclosure}

The authors report no conflicts of interest in this work.

\section{References}

1. United Nations. World population aging [report]. 2015. Available from: http://www.un.org/en/development/desa/population/publications/pdf/ ageing/WPA2015_Report.pdf. Accessed May 2, 2017.

2. Vann MR, Bass PF. The 15 most common health concerns for seniors. 2016. Available from: http://www.everydayhealth.com/news/mostcommon-health-concerns-seniors/. Accessed May 2, 2017.

3. Langa KM. Is the risk of Alzheimer's disease and dementia declining? Alzheimers Res Ther. 2015;7(1):34.

4. World Health Organization. 10 facts on dementia. 2016. Available from: http://www.who.int/features/factfiles/dementia/en/. Accessed May 2, 2017.

5. Kirshner HS. Frontotemporal dementia and progressive aphasia, a review. Neuropsychiatr Dis Treat. 2014;10:1045-1055.

6. Klimova B, Maresova P, Valis M, Hort J, Kuca K. Alzheimer's disease and language impairments: social intervention and medical treatment. Clin Interv Aging. 2015;10:1401-1408.

7. Maresova P, Klimova B, Kuca K. Alzheimer's disease: cost cuts call for novel drugs development and national strategy. Ceska Slov Farm. 2015; 64:25-30.
8. Karakaya T, Fußer F, Schröder J, Pantel J. Pharmacological treatment of mild cognitive impairment as a prodromal syndrome of Alzheimer's disease. Curr Neuropharmacol. 2013;11(1):102-108.

9. Stern Y. Cognitive reserve: implications for assessment and intervention. Folia Phoniatr Logop. 2013;65(2):49-54.

10. Antoniou M, Gunasekera GM, Wong PC. Foreign language training as cognitive therapy for age-related cognitive decline: a hypothesis for future research. Neurosci Biobehav Rev. 2013;37(10 Pt 2):2689-2698.

11. Fischer A, Sananbenesi F, Wang X, Dobbin M, Tsai LH. Recovery of learning and memory is associated with chromatin remodelling. Nature. 2007;447(7141):178-182.

12. McClearn GE, Johansson B, Berg S, et al. Substantial genetic influence on cognitive abilities in twins 80 or more years old. Science. 1997; 276(5318):1560-1563.

13. Klimova B, Kuca K. Alzheimer's disease: potential preventive, noninvasive, intervention strategies in lowering the risk of cognitive decline - a review study. J Appl Biomed. 2015;13(4):257-261.

14. Bak T. Language lessons to help protect against dementia. BMJ. 2016; 354:i5039.

15. Cheng KW, Deng YH, Li M, Yan HM. The impact of L2 learning on cognitive aging. ADMET DMPK. 2015;3(3):260-273.

16. Kaiwen C, Yanhui D, Dezhong Y. Bilingualism (multilingualism) helps resist Alzheimer's disease? Adv Psychol Sci. 2014;22(11):1723-1732.

17. Bak TH, Nissan JJ, Allerhand MM, Deary IJ. Does bilingualism influence cognitive aging? Ann Neurol. 2014;75(6):959-963.

18. Goral M, Campanelli L, Spiro A 3rd. Language dominance and inhibition abilities in bilingual older adults. Biling (Camb Engl). 2015;18(1): $79-89$.

19. Luk G, Bialystok E, Craik FI, Grady CL. Lifelong bilingualism maintains white matter integrity in older adults. J Neurosci. 2011;31(46): 16808-16813.

20. Schweitzer TA, Ware J, Fischer CE, Craik FI, Bialystok E. Bilingualism as a contributor to cognitive reserve: evidence from brain atrophy in Alzheimer's disease. Cortex. 2012;48(8):991-996.

21. Grundy JG, Anderson JAE, Bialystok E. Neural correlates of cognitive processing in monolinguals and bilinguals. Ann N Y Acad Sci. 2017; 1396(1):183-201.

22. Abutalebi J, Canini M, Della Rosa PA, Green DW, Weekes BS. The neuroprotective effects of bilingualism upon the inferior parietal lobule: a structural neuroimaging study in aging Chinese bilinguals. J Neurolinguistics. 2015;33:3-13.

23. Olsen RK, Pangelinan MM, Bogulski C, et al. The effect of lifelong bilingualism on regional grey and white matter volume. Brain Res. 2015; 1612:128-139.

24. Perani D, Farsad M, Ballarini T, et al. The impact of bilingualism on brain reserve and metabolic connectivity in Alzheimer's disease. Proc Natl Acad Sci U S A. 2017;114(7):1690-1695.

25. Estanga A, Ecay-Torres M, Ibañez A, et al. Beneficial effect of bilingualism on Alzheimer's disease CSF biomarkers and cognition. Neurobiol Aging. 2017;50:144-151.

26. Bialystok E, Craik FI, Freedman M. Bilingualism as a protection against the onset of symptoms of dementia. Neuropsychologia. 2007; 45(2):459-464.

27. Lee RR, Tzeng OJ. Neural bilingualism: a new look at an old problem. Lang Linguist. 2016;17(2):147-193.

28. Schlegel AA, Rudelson JJ, Tse PU. White matter structure changes as adults learn a second language. J Cogn Neurosci. 2012;24(8): 1664-1670.

29. Bialystok E. The structure of age: in search of barriers to second language acquisition. Second Lang Res. 1997;13(2):116-137.

30. Moher D, Liberati A, Tetzlaff J, Altman DG; The PRISMA Group. Preferred reporting items for systematic review and meta-analysis: the PRISMA statement. PLoS Med. 2009;6(6):e1000097.

31. Alladi S, Bak TH, Shailaja M, et al. Bilingualism delays the onset of behavioural but not aphasic forms of frontotemporal dementia. Neuropsychogia. 2017;99:207-212. 
32. Hindle JV, Martin-Forbes PA, Bastable AJ, et al. Cognitive reserve in Parkinson's disease: the effects of Welsh-English bilingualism on executive function. Parkinsons Dis. 2015;2015:943572.

33. Calabria M, Branzi F, Marne P, Hernandez M, Costa A. Age-related effects over bilingual language control and executive control. Biling Lang Cogn. 2015;18(1):65-78.

34. Chertkow H, Whitehead V, Phillips N, Wolfson C, Atherton J, Bergman H. Multilingualism (but not always bilingualism) delays the onset of Alzheimer disease: evidence from a bilingual community. Alzheimer Dis Assoc Disord. 2010;24(2):118-125.

35. Liu YC, Liu YY, Yip PK, Meguro M, Meguro K. Speaking one more language in early life has only minor effects on cognition in Taiwanese with low education level: the Taishan Project. Psychogeriatrics. 2017; 17(4):256-261.

36. Lawton DM, Gasquoine PG, Weimer AA. Age of dementia diagnosis in community dwelling bilingual and monolingual Hispanic Americans. Cortex. 2015;66:141-145.

37. Sanders AE, Hall CB, Katz MJ, Lipton RB. Non-native language use and risk of incident dementia in the elderly. J Alzheimers Dis. 2012; 29(1):99-108.

38. Wilson RS, Boyle PA, Yang J, James BD, Bennett DA. Early life instruction in foreign language and music and incidence of mild cognitive impairment. Neuropsychology. 2015;29(2):292-302.

39. Yeung CM, St John PD, Menec V, Tyas SL. Is bilingualism associated with a lower risk of dementia in community-living old adults? Crosssectional and prospective analyses. Alzheimer Dis Assoc Disord. 2014; 28(4):326-332.

40. Zahodne LB, Schofield PW, Farrell MT, Stern Y, Manly JJ. Bilingualism does not alter cognitive decline or dementia risk among Spanish speaking immigrants. Neuropsychology. 2014;28(2):238-246.

41. Alladi S, Bak TH, Duggirala V, et al. Bilingualism delays age at onset of dementia, independent of education and immigration status. Neurology. 2013;81(22):1938-1944.

42. Bialystok E, Craik FI, Binns MA, Ossher L, Freedman M. Effects of bilingualism on the age of onset and progression of $\mathrm{MCI}$ and $\mathrm{AD}$ : evidence from executive function tests. Neuropsychology. 2014;28(2): 290-304

43. Clare L, Whitaker CJ, Craik FI, et al. Bilingualism, executive control, and age at diagnosis among people with early-stage Alzheimer's disease in Wales. J Neuropsychol. 2014;10(2):163-185.

44. Craik FI, Bialystok E, Freedman M. Delaying the onset of Alzheimer disease: bilingualism as a form of cognitive reserve. Neurology. 2010; 75(19):1726-1729.

45. Gollan TH, Salmon DP, Montoya RI, Galasko DR. Degree of bilingualism predicts age of diagnosis of Alzheimer's disease in low-education but not in highly educated Hispanics. Neuropsychologia. 2011;49(14): 3826-3830.
46. Ossher L, Bialystok E, Craik FI, Murphy KJ, Troyer AK. The effect of bilingualism on amnestic mild cognitive impairment. J Gerontol B Psychol Sci Soc Sci. 2013;68(1):8-12.

47. Woumans E, Santens P, Sieben A, Versijpt J, Stevens M, Duyck W. Bilingualism delays clinical manifestation of Alzheimer's disease. Biling Lang Cogn. 2015;18(3):568-574.

48. Wells GA, Shea B, O'Connell D, et al. The Newcastle-Ottawa Scale (NOS) for assessing the quality of nonrandomized studies in metaanalyses. Available from: http://www.ohri.ca/programs/clinical_epidemiology/oxford.asp. Accessed July 25, 2017.

49. Bakker M. Power problems: $\mathrm{n}>138$. Cortex. 2015;73:367-368.

50. Cohort Studies. Prospective versus retrospective cohort studies. 2016. Available from: http://sphweb.bumc.bu.edu/otlt/MPH-Modules/EP/ EP713_CohortStudies/EP713_CohortStudies2.html. Accessed May 8, 2017.

51. Abutalebi J, Clahsen H. Bilingualism, cognition, and aging. Biling Lang Cogn. 2015;18(1):1-2.

52. Bialystok E, Abutalebi J, Bak TH, Burke DM, Kroll J. Aging in two languages: implications for public health. Ageing Res Rev. 2016;27: 56-60.

53. Alvarez A, Rodriguez M. The effects of bilingualism on cognitive decline in mild cognitive impairment (MCI) and Alzheimer's disease (AD). Arch Clin Neuropsychol. 2016;31(6):594.

54. Mukadam N, Sommerland A, Livingston G. The relationship of bilingualism compared to monolingualism to the risk of cognitive decline or dementia: a systematic review and meta-analysis. J Alzheimers Dis. 2017;58(1):45-54

55. Paap KR, Johnson HA, Sawi O. Should the search for bilingual advantages in executive functioning continue? Cortex. 2016;74:305-314.

56. Calvo V, García AM, Manoiloff L, Ibáñez A. Bilingualism and cognitive reserve: a critical overview and a plea for methodological innovations. Front Aging Neurosci. 2016;7:249.

57. Fuller-Thomson E, Kuh D. The healthy migrant effect may confound the link between bilingualism and delayed onset of Alzheimer's disease. Cortex. 2014;52:128-130.

58. Strauss S. Does bilingualism delay dementia? CMAJ. 2015;187(7): E209-E210.

59. Melby-Lervåg $M$, Hulme $C$. There is no convincing evidence that working memory training is effective: a reply to Au et al (2014) and Karbach and Verhaeghen (2014). Psychon Bull Rev. 2016;23(1): 324-330.

60. Melby-Lervåg M, Hulme C. Is working memory training effective? A meta-analytic review. Dev Psychol. 2013;49(2):270-291.

61. Kurdziel LB, Mantua J, Spencer RM. Novel word learning in older adults: a role for sleep? Brain Lang. 2017;167:106-113.
Clinical Interventions in Aging

\section{Publish your work in this journal}

Clinical Interventions in Aging is an international, peer-reviewed journal focusing on evidence-based reports on the value or lack thereof of treatments intended to prevent or delay the onset of maladaptive correlates of aging in human beings. This journal is indexed on PubMed Central, MedLine,

\section{Dovepress}

CAS, Scopus and the Elsevier Bibliographic databases. The manuscript management system is completely online and includes a very quick and fair peer-review system, which is all easy to use. Visit http://www.dovepress. com/testimonials.php to read real quotes from published authors. 